\title{
AC 2011-1130: TEACHING CHEMICAL ENGINEERING CONCEPTS TO NONCHEMICAL ENGINEERS: INDIGO: A WORLD OF BLUES
}

Polly R. Piergiovanni, Lafayette College

Polly R. Piergiovanni is an Associate Professor in the Department of Chemical and Biomolecular Engineering at Lafayette College. She teaches the introductory engineering and chemical engineering courses, as well as process control. Her research interests include process control, biochemical engineering and the dyeing process. 


\section{Teaching Chemical Engineering Concepts to Nonchemical Engineers Indigo: A World of Blues A Chemical Engineering Course For Nonengineers}

Dip white fabric in the muddy-colored indigo dye vat, and the cloth emerges green, then slowly turns azure, cobalt or sapphire before your eyes. The chemistry behind this reaction will be revealed - and practiced - in this course. This mysterious dye has an intriguing history, and we will study its societal and environmental impact from antiquity to the present. We will explore the use of indigo by different cultures, and each student will have the opportunity to replicate one of the techniques used to dye fabric with indigo. We will learn about the equipment used in producing indigo dye, and the three sources of indigo: synthetic, natural, and biosynthetic. The course will culminate with the design of a new indigo production facility. Students will need to determine what type of indigo to produce, the location of the facility (i.e., rural or populated area? How will it impact the population?), what environmental concerns to consider and other aspects of a new facility.

This course description was provided to all sophomore students at Lafayette College and 20 students chose to enroll in the course. Several of the students had not taken any lab science courses in college and over a quarter had not had a math course since high school. About half were chemical engineering majors. How does one teach process engineering to such a diverse group?

The first step was to determine what I wanted to communicate to the students; that is, I needed to establish learning outcomes. I selected the following objectives:

By the end of the semester, students will be able to:

1. Use multiple perspectives to answer important questions about a complicated problem

2. Explain the chemical differences between dyeing with indigo and dyeing with other natural dyes

3. Create a process flow diagram, identify major process equipment and explain briefly how they work

4. Write a technically competent laboratory report on the processes studied

5. Show an understanding of what a professional is and the ethical responsibilities of a professional

Each week, the students spent two hours in class and two hours in the lab. Many active learning exercises were developed for the class time, and I created seven laboratory experiences. This paper presents descriptions of the active learning and laboratory exercises, an assessment of the results and lessons learned from teaching engineering to students who are not engineers. 


\section{Background Information}

Our society is driven by technology, and everyone needs to understand something about engineering ${ }^{1}$. This is the logic behind the Values and Science/Technology (VaST) requirement at Lafayette College. Every sophomore is required to take a VaST course, chosen from a list of about 25 options. Each VaST course is about a different topic, but all present some aspect of science and/or technology interacting with a variety of other disciplines. The courses also address ethical or values-oriented concerns and include processed writing ${ }^{2}$. The VaST course has been required for many years, and is considered to be a fundamental component of the students' education. The College provides nearly $\$ 1000$ to the instructor for books and materials for each VaST course.

According to Turbak and Berg ${ }^{3}$, introducing some engineering to all students is important because

- Students learn by doing, and engineering is often taught by having students create or design something. Students learn and remember best when they are actively engaged in the process, and they become better problem solvers. This is as important for liberal arts students as it is for engineers.

- Students will gain some technological literacy. Literacy is an important goal of the liberal arts education. Students need to understand and appreciate the modern world to be able to make informed decisions about critical issues.

- Students who understand the big ideas of engineering (for example, recognizing real-world constraints, trade-offs, and considerations of economics, environment and safety) may later understand their own discipline better.

Others agree that engineering should be a component of the liberal arts education. Union College has a curriculum, called Converging Technologies, which integrates the arts, humanities and sciences with engineering ${ }^{4}$. The president of Smith College stated that "the study of science and engineering should enrich and deepen the education of historians and poets" ${ }^{\text {" }}$. The challenge to engineers is to encourage students to enroll in the classes, and make the information accessible to the students.

In developing this course, I decided that the information provided to the students would be accessible to those with a background that included little chemistry and no calculus. By giving the students the opportunity to "do" engineering, I hoped that they would learn and remember more. I wanted to expose the students to some broad concepts and principles that would help them have a better understanding of what engineering is, but not directly prepare them to practice engineering, similar to the robotics course created by Turbak and Berg ${ }^{3}$.

After completing the course, I wanted students to know, for example, the purpose of filtration, why it is important to know about tubing sizes and schedules, or why some reactions result in colored substances. They would not be able to model a process, but they would be able to put some unit operations into a useful order to produce a product. By being able to do this, the students might change their view of chemical plants, and have a better understanding of environmental and safety concerns. 


\section{Course Organization}

The course had two 1-hour lecture times and one 2-hour laboratory time each week. The lecture times were seldom actually lectures, but most often included active learning exercises or short presentations by the students on the topics. The class was divided into four subjects, with a short quiz after each subject. The first subject was the history of indigo, followed by the processing of indigo (including unit operations and design of a plant), and the chemistry of indigo synthesis. The third topic was a unit on ethics (required for all VaST courses) and the final topic was cultural and artistic uses of indigo.

Students purchased a book for the course ${ }^{6}$, were directed to resources available in the library ${ }^{7,8}$ and were given several journal articles we discussed in class ${ }^{9-14}$.

The group of students was diverse, including twelve chemical engineering majors, and eight liberal arts students (majoring in economics, psychology, history and art). Many of the students had taken a semester of calculus. I still limited the mathematical content of the course to basic algebra, and provided extra help outside of class for those who needed it. We also met once in a computer classroom where I introduced all of the students to Visio (to draw a simple Process Flow Diagram) and Excel (for creating graphs). Two of the students were especially concerned about their lack of chemistry background. I provided multiple explanations (using the chalkboard, manipulatives, and animations) for the chemical reactions they needed to learn, and, more importantly, personally helped them perform the synthesis laboratory experiments.

\section{Active Learning Exercises}

Most information was presented to the students during the one-hour time period, and active learning exercises were used whenever I could develop them. Four are described below.

- Timeline activity: The first weeks of the class covered the history of indigo, starting at about $3000 \mathrm{BC}$. I wanted the students to be able to mark the events in indigo history with events they had already learned about, so their first assignment was to come to class with six events that took place between $3000 \mathrm{BC}$ and $500 \mathrm{BC}$ : three that they already had learned about, and three that had something to do with indigo, agriculture or art. At the beginning of class, I drew a timeline on the blackboard on two sides of the classroom, and each student wrote their events on the timeline (along with their initials). As we marched through time, I illustrated important events in indigo history. Their additions led to an interesting history lesson, and we had a chance to get to know each other.

- New York Times articles: From 1874 to about 1900, the New York Times published many articles about the synthesis of indigo by the Germans, the commerce of indigo, and how the artificial indigo would change the world. I printed copies of the original articles, pasted them to cardstock, and arranged them around the classroom. The students were divided into groups, and given questions that could be answered from reading the articles. A competition 
developed as the groups tried to find the answers, and the students found it more interesting than just reading the articles on their own. They also learned how journalism and vocabulary have changed in the last 100 years or so.

- Unit Operations examples: One portion of the course covered the unit operations that are part of indigo production and dyeing (pumping, mixing, filtration, drying, primarily). I brought samples of different schedule pipes and tubing to class, and different types of propellers and turbine mixers, so the students could hold and examine them. In addition, I took apart an old pump and valves, so the students could examine how they worked while I explained it on the board. We took a tour of the Unit Operations laboratory to show the students the larger pieces of equipment. This was likely the first time most of the students had been in a facility with this type of equipment. The students knew something about distillation, filtration, and other processes, but most had not seen the equipment used in plants.

- Plant Design Game: I wanted students to realize that when designing a plant, decisions must be made, and the decisions had economic as well as other consequences. With one week devoted to the topic, we didn't have time to cover how the decisions were made (although we did discuss synthesis trees). Instead, I devised a game where the students made their decisions by pulling slips of paper out of a hat and rolling dice. This gave them the information so they could construct a basic economic statement for their plant, and determine their profit (or loss). It was a lively competition (with a candy bar for the student with the largest profit) and the role of decisions became clear to the students.

In addition to these games, videos on YouTube were used to demonstrate dye making and printing techniques, DVDs gave us a tour through a Shibori plant in Japan, and students gave several presentations on various topics. We were also fortunate to be invited to tour a nearby pigment plant, where the students saw full size examples of the unit operations and safety measures we had discussed.

\section{$\underline{\text { Laboratories }}$}

The students met in the laboratory on Fridays for two hours for different activities. About half the activities were done individually, and half done in a group of two or three (with each group including at least one engineer). The exercises are described below. In addition, I had planned to have the students extract indigo from the plant leaves, but I was unable to keep my plants alive through the Pennsylvania winter. Dead plants do not yield measurable indigo.

1. Natural dyes and the necessity of mordants: Each student was given a bundle of fabric: three pieces each of linen, wool, cotton and silk, mordanted with either chrome, tin or alum. Each piece of fabric was cut into four pieces so each combination could be dyed in one of the four natural dyes (logwood, fustic, Brazilwood or cochineal). Each student then had 48 pieces of fabric. The 
assignment was to organize them creatively and draw conclusions on the effect of fabric, mordant and dye.

2. Demonstration of how to begin and maintain a vat of natural indigo, emphasizing the harmful effect of excess oxygen.

3. Indigo dyeing: Each student was given pieces of cotton, silk, wool and linen to dye with natural indigo. They learned the importance of physically working the dye into the fabric and got to see it turn from green to blue as the cloth hung to dry.

4. Unit Operations experiments (performed in groups, individual memos): In class, we discussed the unit operations used in the production of indigo. Most unit operations are too complicated for nonengineers to analyze, but some smaller parts are more easily understood. Using a pump designed for a small outdoor fountain, the students collected data for a pump curve, which they created in Excel. They calibrated a variable area rotameter, and wrote a paragraph describing how it works. Last, using a Girder and Panel hydrodynamic building $\operatorname{set}^{15}$, they constructed a continuous process (with water circulating) and observed the response of the system when various valves were closed, and described how a siphon in the process worked.

5. Synthesis of indigo: Using benzaldeyde, acetone and $\mathrm{NaOH}$, each student synthesized indigo. Before beginning the lab, they had to show me that they had found and summarized the MSDS for each component. I demonstrated the use of a graduated cylinder, analytical scale and Buchner funnel for the nonengineering students. All students were instructed on yield calculations and waste disposal.

6. Project weeks: The students were given a white cotton dish towel, access to the dyes and other materials, and encouraged to create something using the artistic techniques we had learned about in class (batik, shibori, and stamping). They also created an advertisement that detailed how their creation was made.

The students enjoyed the time in the laboratory, asked insightful questions and produced good memos. One student (a chemical engineer) created a magnificent display from the first experiment that made it easy for an observer to draw conclusions on the effect of mordant and fabric (see Figure 1). We spent two weeks dyeing with indigo, to get deeper colors. Many students discovered they had rinsed their fabric too early the first week, and therefore rinsed off the indigo. They were able to correct this the second week. Later, when we discussed the different modes of dye attachment, this was easy for them to understand. I was impressed by the explanations of how a rotameter works. Both engineers and nonengineers were able to use the resources I provided ${ }^{16,17}$ to describe how the variable area influences the measurement. The engineers used equations, the nonengineers used words, but both communicated effectively. 
Figure 1. Display created by student TO showing how different natural dyes, mordants, and fabrics combine for a rainbow of colors.
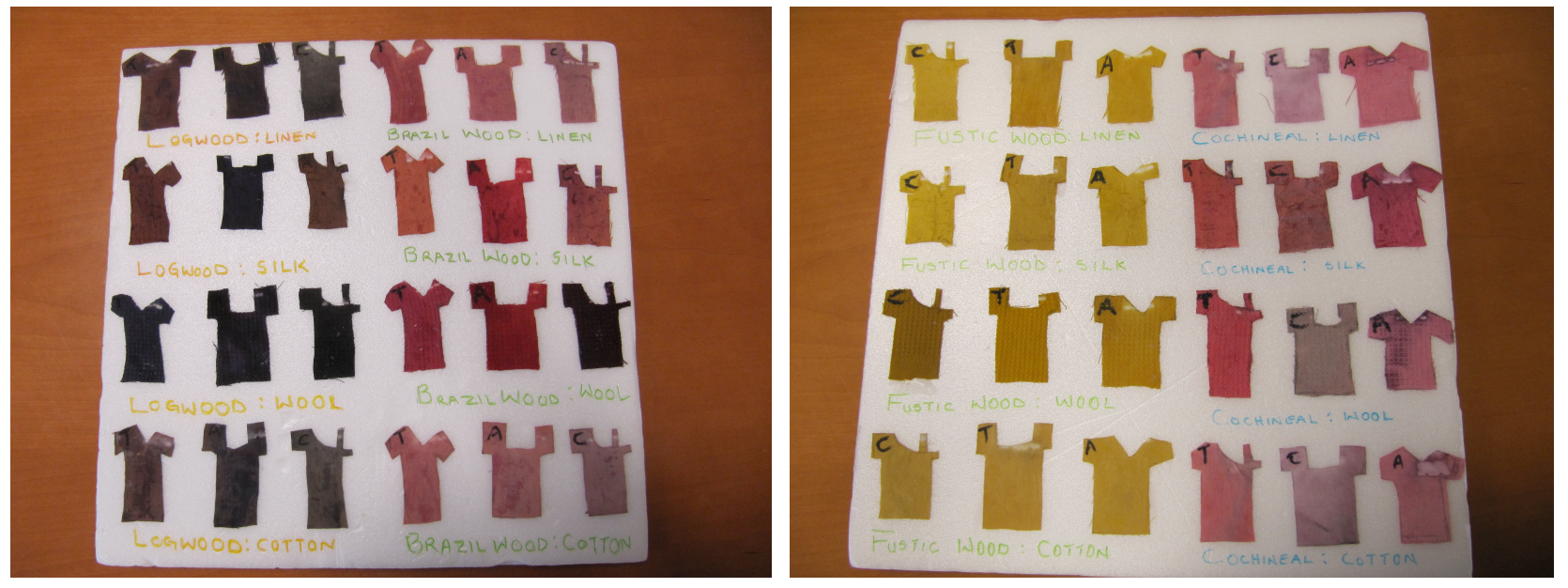

The engineers had no trouble synthesizing indigo (they had completed organic chemistry lab by this point), and most of the nonengineers were able to do the lab with little help. However, one student never was able to quite understand any of the steps. Eventually, after class I walked her through the procedure step by step and she was able to produce a small amount of indigo.

The students created works of art at the end of the semester. I was proud of the different techniques they were willing to try, and how their efforts turned out. Many were given to their mothers as gifts for Mother's Day. We had an unforgettable lesson in reading MSDS sheets, when some (unsupervised) students turned the heat up to high on melting paraffin (for batik) and it caught fire. If they had first read the MSDS sheet, they would have melted the paraffin in a water bath.

\section{$\underline{\text { Assessment }}$}

The main assessment (to measure knowledge of engineering gained, and to assess learning objective 1) was performed on the final paper of the class, where the students had to design a plant to produce either natural, synthetic or biosynthetic indigo. The papers were analyzed according to the following questions:

1. Were safety and environmental concerns addressed?

2. Did the student exhibit an understanding of the chemistry behind the process?

3. Were unit operations described correctly (focusing on agitation, extraction and filtration)?

I read the papers multiple times, and compiled notes in a master sheet (see Table 1 for the analysis of two nonengineering students' papers). A summary of the results from eight nonengineering students is shown in Table 2. Most of the students were able to describe the chemistry and unit operations adequately, although one student included some misstatements about the chemistry of nitrogen. Four students who attempted to describe the fermentation process did so correctly. All students excelled on describing the 
measures they would take to protect workers and the environment, and provided the inspiration with good writing. For example, SA wrote, "Blue Earth uses $19^{\text {th }}$ century methods but treats workers and uses farming techniques with a $21^{\text {st }}$ century outlook" and CP wrote, "This industrial factory will create blue but stay "Green"”. One student (CP) was creative and described how his factory would meet LEED certification, and chose his equipment so the factory could be changed from producing natural indigo to biosynthetic indigo once the biosynthetic method became more reproducible. Another student (JW) created a contract between her company and Genocor to share the biosynthetic technology between them. As I read the papers, I could often discern the student's interests and major. For example, KB (a history major) wrote "A plant [indigo] that has such an interesting history deserves to continue making history". After reading and grading these papers, I was convinced that the students had met the objectives of the course.

Table 1. Final Plant Design Paper Assessment - Data for two sample students.

\begin{tabular}{|c|c|c|c|c|c|}
\hline \multirow{2}{*}{$\begin{array}{l}\text { Student } \\
\text { (type of } \\
\text { indigo) }\end{array}$} & \multirow{2}{*}{$\begin{array}{l}\text { Safety \& } \\
\text { Environment } \\
(10 \mathrm{pts}) \\
\end{array}$} & \multirow{2}{*}{$\begin{array}{l}\text { Chemistry } \\
\text { (10 points) }\end{array}$} & \multicolumn{3}{|c|}{ Unit Operations } \\
\hline & & & $\begin{array}{l}\text { Agitation } \\
\text { (10 points) }\end{array}$ & $\begin{array}{l}\text { Extraction } \\
\text { (10 points) }\end{array}$ & $\begin{array}{l}\text { Filtration } \\
\text { (10 points) }\end{array}$ \\
\hline $\begin{array}{l}\text { SA } \\
\text { (natural) }\end{array}$ & $\begin{array}{l}\text { Educate and } \\
\text { train workers } \\
\text { Pay well for } \\
\text { good workers } \\
\text { Use leaves as } \\
\text { fertilizer } \\
\text { Keep seeds } \\
\text { for the next } \\
\text { crop } \\
10\end{array}$ & $\begin{array}{l}\text { Rotate crops (rice } \\
\text { and indigo) to } \\
\text { avoid nitrogen } \\
\text { depletion } \\
\text { Oxygen dissolves } \\
\text { indoxyl producing } \\
\text { indigotan } \\
10\end{array}$ & $\begin{array}{l}\text { Incorporates } \\
\text { oxygen to } \\
\text { cause } \\
\text { reaction of } \\
\text { indoxyl to } \\
\text { indigotan } \\
10\end{array}$ & $\begin{array}{l}\text { Leaching - } \\
\text { takes the } \\
\text { indoxyl out } \\
\text { of the } \\
\text { leaves and } \\
\text { dissolves it } \\
\text { in the water } \\
10\end{array}$ & $\begin{array}{l}\text { Uses cloth } \\
\text { to catch } \\
\text { indigotan } \\
\text { precipitate } \\
9\end{array}$ \\
\hline $\begin{array}{l}\mathrm{AE} \\
\text { (natural) }\end{array}$ & $\begin{array}{l}\text { Leaves make } \\
\text { rich compost. } \\
\text { Crop rotation. } \\
\text { Production } \\
\text { will be ethical } \\
\text { and fair to } \\
\text { farmers } \\
10\end{array}$ & $\begin{array}{l}\text { "No harmful } \\
\text { chemicals are } \\
\text { allowed to be } \\
\text { used that would } \\
\text { take nutrients } \\
\text { away from the } \\
\text { soil" "By } \\
\text { avoiding } \\
\text { pesticides, } \\
\text { microorganisms } \\
\text { are killed off" } \\
\text { Indigo plants are } \\
\text { nitrogen hungry } \\
6\end{array}$ & $\begin{array}{l}\text { Agitate with } \\
\text { paddles until } \\
\text { water is } \\
\text { oxidized } \\
10\end{array}$ & $\begin{array}{l}\text { Will extract } \\
\text { dye - no } \\
\text { leaf } \\
\text { fragments } \\
\text { in product - } \\
\text { but no other } \\
\text { description } \\
6\end{array}$ & $\begin{array}{l}\text { To remove } \\
\text { plant } \\
\text { leaves } \\
8\end{array}$ \\
\hline
\end{tabular}


Table 2. Final Plant Design Paper Assessment - Summary data for eight nonengineering students.

\begin{tabular}{|l|l|l|l|l|l|}
\hline Student & $\begin{array}{l}\text { Safety \& } \\
\text { Environment }\end{array}$ & \multirow{2}{*}{ Chemistry } & \multicolumn{3}{|c|}{ Unit Operations } \\
\cline { 4 - 6 } & & & Agitation & Extraction & Filtration \\
& $(10 \mathrm{pts})$ & $(10$ points $)$ & $(10$ points $)$ & $(10$ points $)$ & (10 points $)$ \\
\hline $\begin{array}{l}\text { Natural: } 5 \\
\text { Synthetic: } 2\end{array}$ & $10 / 10$ & $8.6 / 10$ & $9.7 / 10$ & $8.9 / 10$ & $8.8 / 10$ \\
Biosynthetic: 2 & & & & & \\
\hline
\end{tabular}

Other assessments (to cover the learning objectives mentioned in the introduction) included four quizzes and several other writing assignments. The first quiz covered the history of indigo production, so the results are not considered in this paper. Also, some of the writing assignments were more creative than technical, and their analysis was not included in this paper.

Quiz 2 covered learning objective 3, and asked questions about pipes, tubes and schedule number, valves and the unit operations we had discussed (filtration, leaching, drying and pumping). Most of the questions required qualitative answers, but a few required algebraic equations to find the answers, including some simple material balances. The nonengineers performed as well as the engineers (see Table 3). Quiz 3 covered learning objective 2, and had fill-in-the-blank questions about the chemistry of color and dyeing, fermentation and synthesis of indigo, and chemistry of natural fibers. The students were quizzed about the history of the synthesis of indigo, and its effect on society. They also needed to know what type of information was contained in an MSDS sheet. Quiz 4 covered ethics and moral theory. The students had to evaluate a statement according to various moral theories, and define how professional ethics apply to various problems in the indigo industry (slavery, small village industry, think of other things to tie together). Both engineers and nonengineers performed similarly on Quiz 4. 
Table 3. Quiz Performance Summary for the eight nonengineering students.

\begin{tabular}{|l|l|c|c|c|}
\hline Student & Major & $\begin{array}{c}\text { Quiz 2 - ChE } \\
\text { (41 points } \\
\text { possible) }\end{array}$ & $\begin{array}{c}\text { Quiz 3 - Chem } \\
\text { (30 points } \\
\text { possible) }\end{array}$ & $\begin{array}{c}\text { Quiz 4 - Ethics } \\
\text { (42 points } \\
\text { possible) }\end{array}$ \\
\hline SA & AB Economics & 40 & 24 & 33 \\
\hline KB & AB History & 36 & 27 & 38 \\
\hline AE & AB Art & 31 & 20 & 35 \\
\hline CH & AB Psychology & 41 & 26 & 39 \\
\hline RI & AB & 40 & 30 & 38 \\
& Math/Economics & & & 28 \\
\hline JK & AB Economics & 40 & 27 & 36 \\
\hline CP & AB Economics & 37 & 29 & 40 \\
\hline JW & AB Psychology & 41 & $26 / 30=88 \%$ & $37 / 42=88 \%$ \\
\hline $\begin{array}{l}\text { Average for nonengineers: } \\
\text { Average for all 20 students: }\end{array}$ & $38 / 41=93 \%$ & $84.4 \%$ & $87.7 \%$ & $88.0 \%$ \\
\hline
\end{tabular}

Learning objective 4 was assessed from reading the laboratory reports the students wrote after laboratory exercises 4 and 5 (unit operations and synthesis of indigo). Both engineers and nonengineers averaged $95 \%$ on both lab reports, for two reasons. First, the students were careful readers and writers, and the lab reports went through two required peer-review sessions. Secondly, most of the nonengineers came to my office for help with the calculations if they were unsure about the procedures. In the end, the assessment shows that the students were able to describe how some simple laboratory equipment works, and describe the synthesis of indigo.

The last form of assessment came from the anonymous student evaluations of the course, completed by 18 of the 20 students. A summary of the evaluations is shown in Table 4 . One student commented that he liked "linking the somewhat eclectic and esoteric topic back to relevant topics such as safety and morality", and a second student wrote that "the mix of science, engineering, writing and art was something different and interesting" comments that show the students understand the purpose of the VaST course. The numerical evaluations indicate that the students liked the course, but placed less value on the specific topic. However, a rating of 4.0 is still "very good". 
Table 4. Student Evaluations of the Course.

\begin{tabular}{|c|c|}
\hline Written Comment & Number of Students \\
\hline Labs put into reality what we were learning & 3 \\
\hline Hands-on dyeing of cloth was particularly useful & 3 \\
\hline Liked creative assignments & 2 \\
\hline Include more ethics & 2 \\
\hline \multicolumn{2}{|c|}{ Numerical Evaluation (Rated 1 to 5, $5=$ Excellent) } \\
\hline Three Highest Characteristics & Three Lowest Characteristics \\
\hline Instructor's enthusiasm (4.9) & $\begin{array}{l}\text { Relevance \& usefulness of course } \\
\text { content (4.0) }\end{array}$ \\
\hline Interest in students' learning (4.8) & Organization (4.1) \\
\hline Examples and illustrations (4.8) & Use of class time (4.3) \\
\hline
\end{tabular}

Future Work

During the Spring 2011 semester, a ChE senior who took the course as a sophomore will be working with me to develop a dyeing kinetics experiment. We have the procedure and the basic analysis developed, and expect to include the experiment in the next course offering. Reviewers of this paper suggested including online safety training modules, which will further support the first and last learning objectives. Currently, due to increased chemical engineering enrollments, it is difficult to find time to teach the course, although the institution is very supportive of the VaST program. We are investigating various solutions to this difficulty.

\section{$\underline{\text { Conclusion }}$}

I developed the course with the learning objectives on page one. At the end of the semester, the students had met and exceeded my objectives. Their papers showed they could understand the multiple perspectives necessary in producing a chemical product, and all created a process flow diagram and identified the unit operations. They creatively explained the differences between indigo dyeing and dyeing with other natural dyes.

Their final papers clearly showed they understood some of the ethical responsibilities of a professional.

I believe the students also learned things beyond the measurable objectives. The students who mentioned at the beginning of the course that they had a fear of chemistry were more comfortable with some basic concepts. Students who would have never entered the engineering building now had some confidence working in one of the labs. Engineering students and nonengineers worked together on presentations and projects. All of this helped to "deepen the education of historians and poets" . 


\section{$\underline{\text { References }}$}

1. Halford, Bethany, "Engineering for Everyone", Prism, Volume 14, Number 4, December 2004.

2. Lafayette College web site, http://vast.lafayette.edu/what-is-vast/what-is-a-vastcourse/ Accessed 1/16/11.

3. Turbak, F. and Berg, R., "Robotic Design Studio: Exploring the Big Ideas of Engineering in a Liberal Arts Environment", Journal of Science Education and Technology, Vol. 11, No 3, Pgs 237 - 253 (2002).

4. Klein, J.D. and Balmer, R., "Engineering, Liberal Arts, and Technological Literacy in Higher Education”, IEEE Technology and Society Magazine, Winter 2007, pages $23-28$.

5. "Engineering and the Liberal Arts: Strangers No Longer" The Chronicle of Higher Education 55.2 (2008) Academic OneFile. Web. 5 Jan. 2011

6. Balfour-Paul, Jenny, Indigo, Archetype Publications Ltd., London 2006.

7. Kirk-Othmer Encyclopedia of Chemical Technology, sections on Dyeing; Dyes, Natural; Dyes, Environmental Chemistry;

8. Ullmann's Encyclopedia of Industrial Chemistry, Indigo and Indigo Colorants

9. Wu, E., Komolpis, K., and Wang, H.Y., "Chemical extraction of indigo from Indigofera tinctoria while attaining biological integrity”, Biotechnology Techniques, 13:567 - 569 (1999).

10. Siva, R., "Status of natural dyes and dye-yielding plants in India", Current Science, 92:916 - 925 (2007).

11. "Artificial Indigo", Bulletin of Miscellaneous Information (Royal Gardens, Kew), pages 33 - 35, March 1898.

12. Ensley, B. D., et al., "Expression of naphthalene oxidation genes in Escherichia coli results in the biosynthesis of indigo", Science 222: $167-17$ ? (1983).

13. Murdock, D., Ensley, B.D., Serdar, C. and Thalen, M., "Construction of metabolic operons catalyzing the De Novo synthesis of indigo in Escherichia coli", Bio/Technology 11:381 - 386 (1993).

14. Moore, S.B. and Ausley, L.W., "Systems thinking and green chemistry in the textile industry", J.Cleaner Production, 12: 585 - 601 (2004).

15. Bridgestreet Toys, http://www.bridgestreettoys.com/products/buildingsets.html, Accessed 1/17/11.

16. Felder, R. M., and Rousseau, R. M., Elementary Principles of Chemical Processes, $3^{\text {rd }}$ Edition, Wiley and Sons, 2004.

17. McCabe, W., Smith, J. and Harriott, P., Unit Operations of Chemical Engineering, $7^{\text {th }}$ Edition, McGraw Hill (2004). 